\title{
KELIMPAHAN STOK, SEBARAN PANJANG, DAN KEMATANGAN IKAN COKLATAN (Scolopsis taeniopterus) DI PERAIRAN LAUT JAWA
}

\author{
Tri Ernawati") dan Badrudin ${ }^{1)}$ \\ 1) Peneliti pada Balai Riset Perikanan Laut, Muara Baru-Jakarta \\ Teregristrasi I tanggal: 26 Januari 2007; Diterima setelah perbaikan tanggal: 15 Mei 2007; \\ Disetujui terbit tanggal: 6 Agustus 2007
}

\begin{abstract}
ABSTRAK
Ikan coklatan (Scolopsis taeniopterus) yang secara taksonomis termasuk famili Nemipteridae adalah salah satu jenis ikan demersal ekonomis penting di Laut Jawa. Data yang dianalisis merupakan sebagian hasil riset dengan K. M. Bawal Putih I pada tahun 2005 dan 2006, serta hasil pengambilan contoh di pangkalan pendaratan ikan Blanakan. Dugaan kepadatan stok pada ke-2 cruise tersebut adalah sekitar 7,0 dan $9,0 \mathrm{~kg} \mathrm{~km}^{-2}$. Dari sebaran frekuensi panjang teridentifikasi bahwa contoh ikan coklatan terdiri atas 1 kelompok umur yang kuat (strong cohort) dengan modus ukuran panjang 16,5 $\mathrm{cm}$. Setelah dipisahkan antara jantan dan betina tampak bahwa, ikan jantan didominasi oleh kelompok ukuran $17,5 \mathrm{~cm}$, sedangkan ikan betina oleh ukuran 16,0 cm. Data tersebut menyiratkan bahwa ukuran ikan coklatan jantan lebih panjang dibandingkan dengan ikan betina. Dari sebaran persen frekuensi kumulatif di mana $50 \%$ dari sebaran tersebut yang mencerminkan Lc (panjang pertama kali tertangkap) tampak bahwa ukuran ikan betina dengan Lc=15,5 cm lebih kecil dari ikan jantan dengan Lc=17,5 cm. Melalui analisis kematangan ovarium, dapat dihitung ukuran ikan coklatan mencapai matang ovarium untuk pertama kali pada panjang $\mathrm{Lm}=15,0 \mathrm{~cm}$. Dari ukuran-ukuran tersebut dapat disimpulkan bahwa sebagian besar ikan coklatan yang tertangkap sudah melewati ukuran pertama kali matang gonad, atau Lc>Lm. Jika kondisi tersebut dapat terus dipertahankan, maka stok ikan coklatan di Laut Jawa pada tingkat upaya yang sama mempunyai peluang yang lebih besar untuk dimanfaatkan secara berkelanjutan.
\end{abstract}

\section{KATAKUNCI: ikan coklatan, kelimpahan stok, sebaran panjang, Lc, Lm, Laut Jawa}

ABSTRACT: Stock density, length distribution, and maturity of lattice monocle bream (Scolopsis taeniopterus) in the Java Sea. By: Tri Ernawati and Badrudin

Lattice monocle bream (Scolopsis taeniopterus) that taxonomically belong to the family Nemipteridae provide one of the economically important demersal fish resources in the Java Sea. Data analyzed were part of the R/V Bawal Putih I cruise results carried out in 2005 until 2006, and from sampling in Blanakan landing place. The estimated stock density of the fish were 7.0 dan $9.0 \mathrm{kgs}$ $\mathrm{km}^{-2}$. From the overall length frequency distribution it is likely that the population of the lattice monocle bream consisted of one strong cohort, with the modus of $16,5 \mathrm{~cm}$. When sexually separated, it is revealed that the male group was dominated by the size of $17,5 \mathrm{~cm}$ length, while the female was dominated by the size of $16,0 \mathrm{~cm}$ length. From these data is likely that average size of the male fish during this observation was bigger than the size of female. From the cumulative percent frequencies distribution it was also observed that $50 \%$ of the distribution that can be assummed as equal to the length of first capture of the female fish, $L c=15,5 \mathrm{~cm}$, seem to be smaller size compare with the male of the $L c=17,5 \mathrm{~cm}$. Through maturity analysis it was calculated that the length of first maturity, $L m=15,0$ $\mathrm{cm}$ length. From these size observations it can be concluded that most of the fish caugth have been mature, where $L c>L m$. Provided that this condition could be maintained at the same level of effort, exploitation of the lattice monocle bream stock could likely be achieved sustainably.

\section{KEYWORDS: lattice monocle bream, stock density, size distribution, Lc, Lm, Java Sea}

\section{PENDAHULUAN}

Ikan coklatan (Scolopsis taeniopterus) adalah salah satu jenis ikan demersal ekonomis penting yang cukup banyak tertangkap dengan alat tangkap yang dioperasikan di dasar perairan seperti trawl dan cantrang di Laut Jawa (Losse \& Dwiponggo, 1977; Beck \& Sudradjat, 1979; Anonymous, 2006).
Berdasarkan pada hasil penelitian di tempat penangkapan ikan Tegalsari Kota Tegal, ikan coklatan yang tertangkap oleh cantang 1.627 ton dalam tahun 2006 dan merupakan jenis ikan yang dominan tertangkap (Anonymous, 2006a). Secara taksonomis, ikan coklatan termasuk ke dalam famili Nemipteridae, atau ikan kurisi. Deskripsi umum menurut Russell (1998) ikan coklatan memiliki badan memanjang, agak 
pipih (compressed), dengan panjang total sekitar 31/2 sampai dengan 33/4 kali tinggi badan. Profil kepala dari rahang atas ke dasar sirip punggung cembung agak terjal. Di bawah mata terdapat duri keras (spine) mengarah ke belakang dengan 2 sampai dengan 3 duri yang lebih kecil di bawah. Bersisik relatif besar, mulai dari bagian kepala antara ke-2 mata. Sirip dubur dengan 3 buah jari-jari sirip keras, jari yang ke-2 menonjol dengan panjang yang sama atau sedikit lebih panjang dari sirip ke-3. Jari-jari pertama dari sirip dada memanjang dan berujung seperti benang (filament). Deskripsi sirip DX, 9; Alll, 7; $P_{1}$ ii 15 sampai dengan 16: $P_{2} \mathrm{I}, 5$.

Warna badan menurut deskripsi Fisher \& Whitehead (1974) bervariasi, jika sudah mati kuning keabu-abuan; satu garis tipis biru antara ke-2 mata pada sambungan antara bagian kepala yang bersisik dan tidak bersisik; 1 garis warna kesumba (purple) diapit dengan garis kuning pucat di atas dan di bawah. Mulai dari mata sampai dengan ke bagian rahang bawah; mungkin terdapat 1 goresan (streak) warna kuning dari duri di bawah mata. Terdapat garis-garis vertikal berwarna kuning, biru memucat pada seluruh bagian badan yang memanjang dan berubah menjadi horisontal pada pangkal sirip ekor dan vertikal lagi pada sirip ekor. Terdapat bintik merah pada bagian atas pangkal sirip dada, sebagian besar pangkal sirip punggung berwarna kekuningan, sepanjang bagian tengah kebiruan dan kuning pada bagian ujung. Terdapat garis vertikal berwarna biru, kuning memucat pada sirip ekor dan bagian ujung lengkungan atas (upper lobe) kekuningan. Pada jenis Scolopsis lain tidak terdapat bintik merah pada pangkal sirip dada dan tidak terdapat garis-garis vertikal sepanjang bagian badan.
Jenis-jenis ikan coklatan (Scolopsis taeniopterus) diduga merupakan jenis ikan khas perairan Paparan Sunda, karena belum ditemukan di perairan lain seperti Samudera Hindia (Munro, 1955; Gloerfelt-Tarp \& Kailola, 1985), Paparan Sahul (Munro, 1967) perairan Pacifik Selatan (Rawlinson et al., 1995), atau perairan Jepang dan sekitar (Nakabo, 2002).

\section{BAHAN DAN METODE}

Data yang digunakan untuk analisis indeks kepadatan stok merupakan sebagian hasil penelitian yang dilakukan di Laut Jawa dengan menggunakan K. M. Bawal Putih I, yang dilaksanakan pada bulan Desember 2005 (30 stasiun yang berhasil) dan bulan Mei 2006 (35 stasiun yang berhasil). Penghitungan indeks kepadatan stok digunakan sesuai dengan Saeger et al., 1976, sebagai berikut:

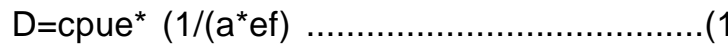

$$
\begin{aligned}
& a=v^{\star} h^{\star} E^{\star} 1,85^{\star}(1 / 1000)
\end{aligned}
$$

di mana:

D = kepadatan stok $\left(\mathrm{kg} \mathrm{km}^{-2}\right)$

cpue = hasil tangkapan ( $\mathrm{kg}$ per jam)

a = luas daerah yang ditrawl

ef $\quad=$ escapement factor $(0,5)$

$\mathrm{v} \quad=$ kecepatan kapal dalam knot $(2,8 \mathrm{knot})$

$\mathrm{h} \quad=$ panjang head rope jaring trawl $(34,6 \mathrm{~m})$

$\mathrm{E} \quad=$ konstansta bukaan head rope $(0,5)$

$1,85=$ konversi mil ke $\mathrm{km}$

$1.000=$ konversi dari meter ke $\mathrm{km}$

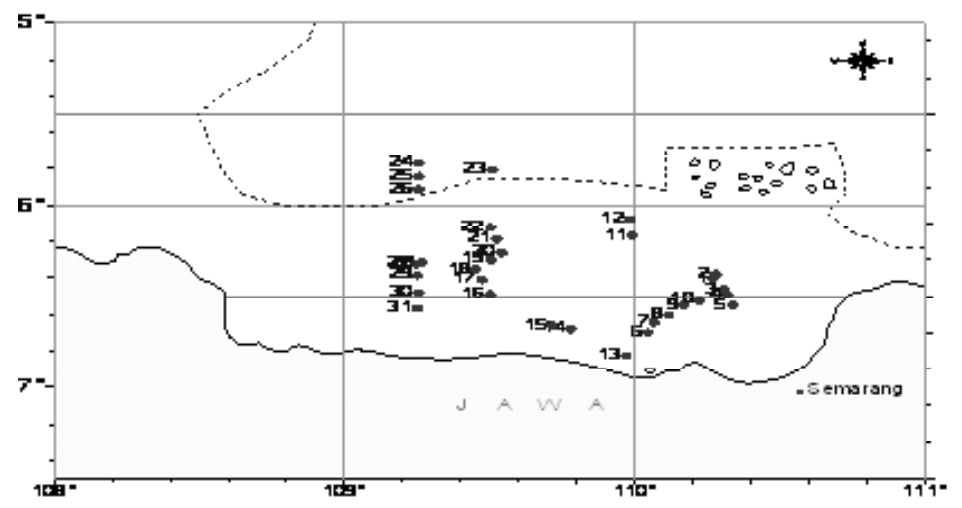

Gambar 1. Posisi stasiun trawl di perairan utara Jawa menggunakan K. R. Bawal Putih I, Desember 2005.

Sumber: Anonymous (2006)

Figure 1. Trawl station position in the north of Java waters using Bawal Putih I vessel research in December 2005.

Sources: Anonymous (2006) 


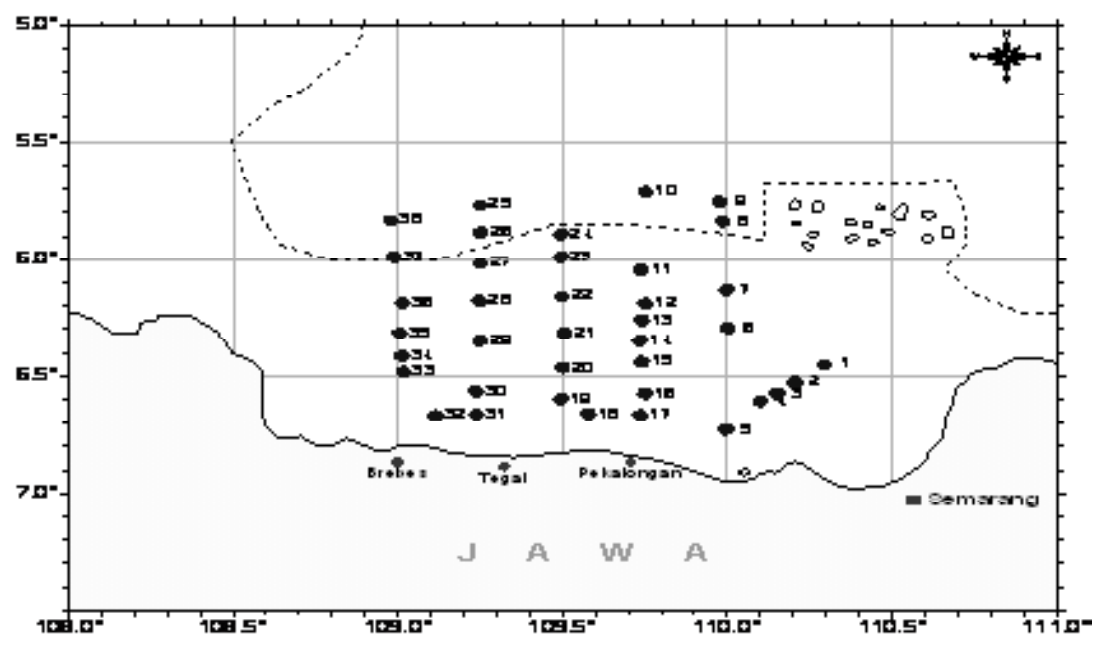

Gambar 2. Posisi stasiun traw/ di perairan utara Jawa menggunakan K. R. Bawal Putih I, Mei 2006. Sumber: Anonymous (2006b)

Figure 2. Trawl station position in the north of the Java waters using Bawal Putih I vessel research in May 2006.

Sources: Anonymous (2006b)

Tabel 1. Tingkat kematangan gonad ikan

Table 1. Gonad maturity stage of fish

\begin{tabular}{|c|c|}
\hline TKG/GMS & Keterangan/Remarks \\
\hline $\begin{array}{l}\text { I } \\
\text { (Belum matang)/ } \\
\text { Immature }\end{array}$ & $\begin{array}{l}\text { Ovarium dan testes, panjang } 1 / 3 \text { rongga perut. Ovarium transparan dan kemerah- } \\
\text { merahan. Telur tidak dapat dilihat dengan mata biasa. }\end{array}$ \\
\hline $\begin{array}{l}\text { II } \\
\text { (Belum matang)/ } \\
\text { Immature }\end{array}$ & $\begin{array}{l}\text { Panjang ovarium sekitar } 1 / 2 \text { rongga perut. Ovarium transparan dan kemerah-merahan. } \\
\text { Telur belum dapat dilihat dengan mata biasa. }\end{array}$ \\
\hline $\begin{array}{l}\text { III } \\
\text { (Matang)/ } \\
\text { Mature }\end{array}$ & $\begin{array}{l}\text { Panjang ovarium dan testes sekitar } 2 / 3 \text { rongga perut.Warna ovarium pink-kuning, } \\
\text { butiran telur sudah tampak. }\end{array}$ \\
\hline $\begin{array}{l}\text { IV } \\
\text { (Matang)/ } \\
\text { Mature }\end{array}$ & $\begin{array}{l}\text { Panjang ovarium } 2 / 3 \text { sampai dengan memenuhi rongga perut. Ovarium berwarna } \\
\text { orange dengan pembuluh darah sudah mulai kurang jelas. Transparan dan butiran } \\
\text { telur terlihat jelas. }\end{array}$ \\
\hline $\begin{array}{c}\mathrm{V} \\
(\text { Spent) }\end{array}$ & $\begin{array}{l}\text { Ovarium mengerut sampai dengan panjang } 1 / 2 \text { rongga perut sebagai tanda pemijahan } \\
\text { tetapi ada butir-butir telur. }\end{array}$ \\
\hline
\end{tabular}

Sumber/Sources: Holden \& Raitt (1974)

Secara umum, posisi stasiun dari ke-2 cruise tersebut tidak mengalami perubahan signifikan (Gambar 1 dan 2).

Untuk analisis sebaran panjang dan tingkat kematangan ikan coklatan dilakukan pengumpulan contoh ikan di pangkalan pendaratan ikan Blanakan, Kabupaten Subang pada bulan Agustus 2006. Contoh ikan coklatan 196 ekor yang terdiri atas 75 ekor betina dan 121 ikan jantan, merupakan sebagian hasil tangkapan cantrang di Laut Jawa.

Identifikasi tingkat kematangan ovarium dilakukan sesuai dengan (Holden \& raitt, 1974), yang terdiri atas 5 tingkatan (Tabel 1).
Pendugaan panjang saat pertama matang ovarium (Length of first maturity, Lm), dilakukan sesuai dengan prosedur penghitungan yang dilakukan Udupa (1968), melalui rumus:

$$
m=X k+X / 2-(X \Sigma p)
$$

di mana:

$\mathrm{m}=\log$ ukuran ikan saat pertama matang ovarium

$X k=\log$ ukuran ikan di mana 100\% ikan contoh sudah matang

$X=$ selang log ukuran (log size increment)

$\mathrm{Pi}=$ proporsi ikan matang pada kelompok ke-i

Rata-rata ukuran ikan pertama kali matang ovarium diperoleh dari nilai Antilog (m). 


\section{HASIL DAN BAHASAN}

\section{Kepadatan Stok Ikan Coklatan}

Pada cruise penelitian yang dilakukan pada bulan Desember 2005, diperoleh hasil tangkapan kelompok kurisi $10 \%$ dari total hasil tangkapan ikan demersal $1.197 \mathrm{~kg}$, di mana jumlah ikan coklatan mencapai $6 \%$ dari total kelompok ikan kurisi. Pada bulan Mei
2006, diperoleh hasil tangkapan kelompok ikan kurisi $13 \%$ dari total hasil tangkapan ikan demersal 3.269 $\mathrm{kg}$, di mana jumlah ikan coklatan mencapai sekitar $3 \%$ dari total kelompok ikan kurisi.

Apabila dibandingkan, hasil tangkapan kelompok ikan kurisi pada tahun 1976 sekitar 3\% dari total laju tangkap $232 \mathrm{~kg}$ per jam dan ikan coklatan sekitar $11 \%$ dari laju tangkap ikan kurisi tersebut (Losse \&

Tabel2. Laju tangkap dan kepadatan stok ikan coklatan (Scolopsis taeniopterus)

Table 2. $\quad$ Catch rate and stock density of lattice monocle bream (Scolopsis taeniopterus)

\begin{tabular}{lcccc}
\hline \multirow{2}{*}{$\begin{array}{c}\text { Jenis } \\
\text { (Species) }\end{array}$} & \multicolumn{2}{c}{$\begin{array}{c}\text { Laju tangkap }(\mathbf{k g} / \mathbf{j a m}) \\
\text { Catch rate }(\mathbf{k g} / \mathbf{h})\end{array}$} & \multicolumn{2}{c}{$\begin{array}{c}\text { Kepadatan stok }\left(\mathbf{k g ~ k m}^{-2}\right) \\
\text { Density }\left(\mathbf{k g ~ k m}^{-2}\right)\end{array}$} \\
\cline { 2 - 5 } & Desember 2005 & Mei 2006 & $\begin{array}{c}\text { Desember } \\
\text { 2005 }\end{array}$ & Mei 2006 \\
\hline Total demersal & 61,3 & 93,4 & 1355 & 2064 \\
Nemipteridae & 6,6 & 15,1 & 146 & 334 \\
Scolopsis taeniopterus & 0,3 & 0,4 & 7 & 9,0 \\
\hline
\end{tabular}

Dwiponggo, 1977). Hasil tangkapan pada tahun 1979, persentase laju tangkap ikan coklatan terhadap ikan kurisi sekitar 12,5\% (Martosubroto, 1982). Pada periode bulan Desember 2005 persentase hasil tangkapan kelompok ikan kurisi $196,9 \mathrm{~kg}$ atau sekitar $11 \%$ dari total laju tangkap ikan demersal $1.840 \mathrm{~kg}$ dan ikan coklatan sekitar $4 \%$ dari hasil tangkapan kelompok ikan kurisi. Kemudian pada bulan Mei 2006 hasil tangkapan kelompok ikan kurisi $528 \mathrm{~kg}$ atau sekitar $16 \%$ dari total laju tangkap ikan demersal $3.269 \mathrm{~kg}$, dan ikan coklatan sekitar 3\% dari hasil tangkapan kelompok ikan kurisi. Pada Tabel 2 disajikan laju tangkap dan kepadatan stok ikan coklatan dibandingkan dengan total ikan demersal dan famili Nemipteridae.

Penyebab menurun persentase ikan coklatan dalam komunitas ikan kurisi tersebut antara lain oleh tekanan panangkapan, interaksi biologis baik dalam bentuk antar hubungan pemangsaan (predator prey relationship) atau persaingan makanan (food competetion) dan penyebab alamiah lain.

Analisis selanjutnya pada Tabel 2 , kepadatan stok ikan coklatan pada bulan Desember 2005 sekitar 7,0 $\mathrm{kg} \mathrm{km}^{-2}$ dan pada bulan Mei 2006 mengalami kenaikan menjadi sekitar $9,0 \mathrm{~kg} \mathrm{~km}^{-2}$. Hal ini, diduga karena pengaruh musim yang berbeda. Bulan Desember adalah musim barat sehingga perairan Laut Jawa pada umumnya terjadi angin dan gelombang besar, sementara bulan Mei sudah memasuki musim peralihan dengan kondisi angin dan gelombang sudah lebih tenang. Hal tersebut, juga diperkuat dari hasil penelitian di pangkalan pendaratan ikan Tegalsari, bahwa produksi ikan coklatan bulan Mei lebih tinggi sekitar 152 ton dibandingkan bulan Desember sekitar

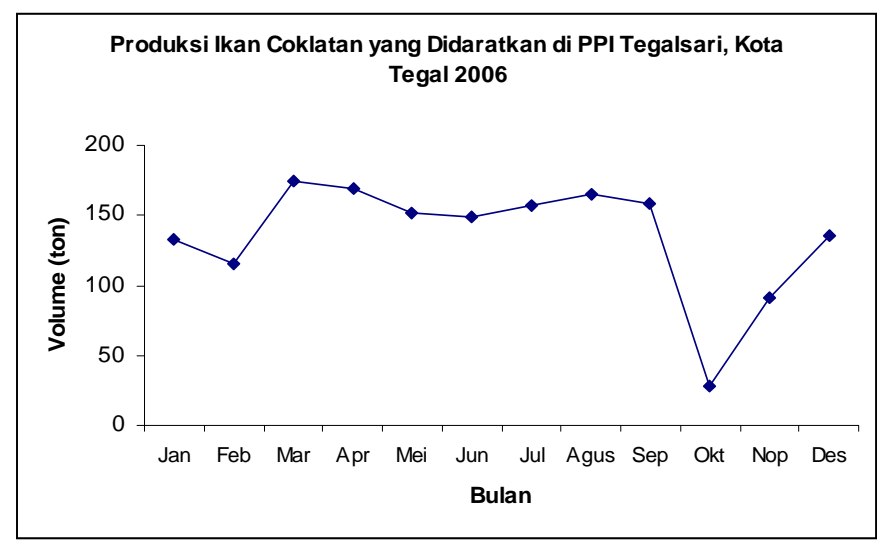

Gambar 3. Produksi ikan coklatan yang didaratkan di pangkalan pendaratan ikan Tegalsari, Kota Tegal 2006.

Figure 3. Production of lattice monocle bream landed in Tegalsari fish landing center, Tegal City 2006. 
136 ton (Gambar 3). Analisis selanjutnya Gambar 3, pada bulan Oktober terjadi penurunan produksi cukup signifikan. Hal ini, disebabkan oleh penurunan jumlah upaya penangkapan yang cukup signifikan karena pengaruh cuaca yang kurang baik. Selain itu, pada bulan tersebut bersamaan dengan bulan Ramadhan.

Pada bulan Mei 2006, dari 35 titik pengambilan contoh penangkapan ikan di perairan Laut Jawa, ikan coklatan dapat diperoleh pada 19 titik pengambilan contoh. Dengan demikian, persen frekuensi kejadian ikan coklatan pada tahun 2006 (54\%). Dibandingkan dengan kondisi tahun 1976 di mana persentase frekuensi kejadian ikan coklatan berada pada kisaran antara 21 sampai dengan 57\% (Losse \& Dwiponggo, 1977) dapat diduga bahwa keberadaan kelompok ikan coklatan dalam komunitas ikan demersal sampai dengan dewasa ini (2006) tidak menunjukkan perubahan yang signifikan.

\section{Sebaran Frekuensi Panjang}

Dari sebaran frekuensi panjang ikan dapat diidentifikasi sejumlah modus-modus kelas umur atau kohort (cohort). Tanpa memisahkan jantan dan betina, dapat diidentifikasi bahwa contoh ikan coklatan terdiri atas 1 kelompok umur yang kuat (strong cohort) pada modus kelompok ukuran panjang sekitar $16,5 \mathrm{~cm}$. Dari fenomena ini belum berarti populasi ikan coklatan di Laut Jawa terdiri atas 1 kohort, sebagaimana tercermin dari sebaran panjang. Mengingat bahwa kisaran panjang yang begitu lebar (14,5 sampai dengan $21,5 \mathrm{~cm}$ ), sebaran tersebut sebenarnya terdiri atas beberapa kohort yang tumpang tindih secara berurutan. Telah diketahui bahwa ikan-ikan tropis terutama ikan berukuran kecil $(<30 \mathrm{~cm} \mathrm{TL})$ pada umumnya tidak melakukan pemijahan secara serentak, sehingga pada survei telur dan larva akan selalu diperoleh sejumlah telur ikan tertentu sepanjang tahun (Delsman, 1932). Dari sebaran panjang ikan petek (Leiognathus splendens) di Laut Jawa dijumpai sejumlah kohort atau multiple cohort yang diduga sebagai akibat dari ada multiple spawning (Badrudin, 1987).

Setelah dipisahkan antara kelompok ikan jantan dan betina tampak bahwa dari kisaran panjang kelompok ikan jantan 14,5 sampai dengan $21,5 \mathrm{~cm}$

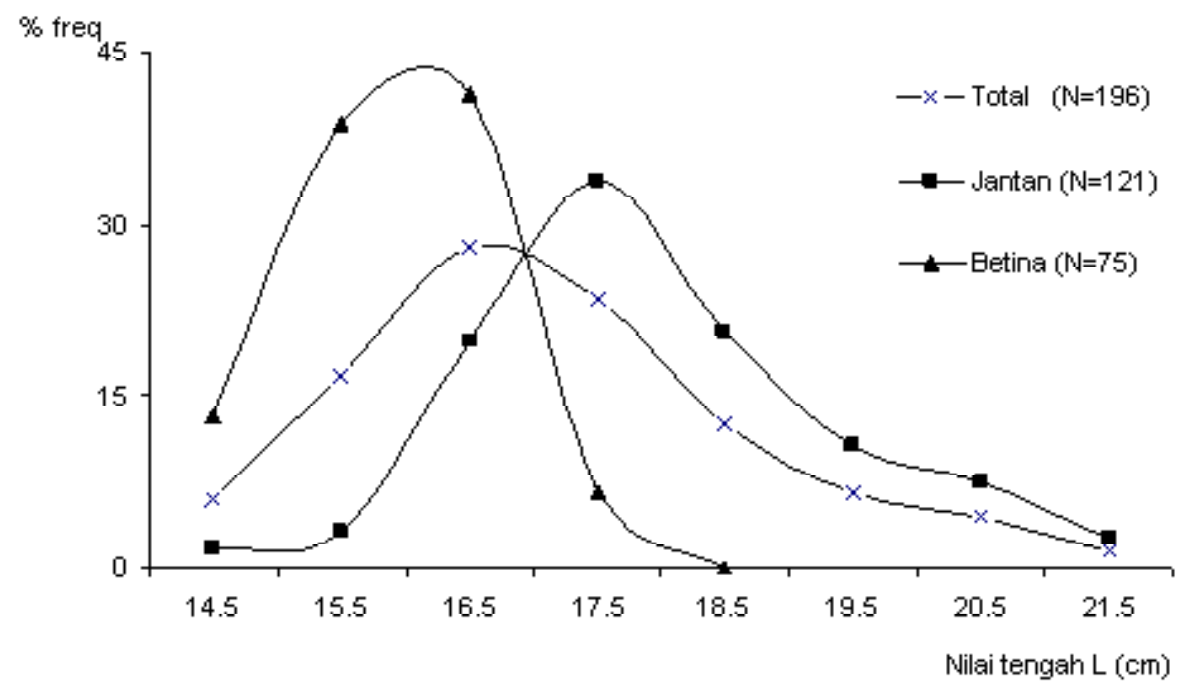

Gambar 4. Frekuensi distribusi (\%) ikan coklatan (S. taeniopterus) jantan dan betina (contoh hasil tangkapan cantrang bulan Agustus 2006, di Laut Jawa).

Figure 4. Distribution frequency (\%) of male and female lattice monocle bream (S. taeniopterus) (cantrang's catch sample in August 2006, from the Java Sea).

didominasi oleh kelompok ukuran panjang $17,5 \mathrm{~cm}$, dan ikan betina pada kisaran yang lebih pendek antara 14,5 sampai dengan $18,5 \mathrm{~cm}$ didominasi oleh ukuran $16,0 \mathrm{~cm}$ (Gambar 4). Dari data tersebut tersirat bahwa kelompok ikan coklatan jantan mempunyai ukuran lebih besar (lebih panjang) dibandingkan dengan ukuran ikan betina.
Dari sebaran persentase frekuensi kumulatif di mana posisi $50 \%$ dari sebaran tersebut mencerminkan Lc (ukuran panjang pertama kali tertangkap) juga tampak bahwa ikan betina dengan $\mathrm{Lc}=15,5 \mathrm{~cm}$ tampak lebih kecil dari ikan jantan dengan $\mathrm{Lc}=17,5$ cm (Gambar 5). Dari fenomena tersebut diduga bahwa kelompok ikan berukuran kecil mempunyai kebiasaan 


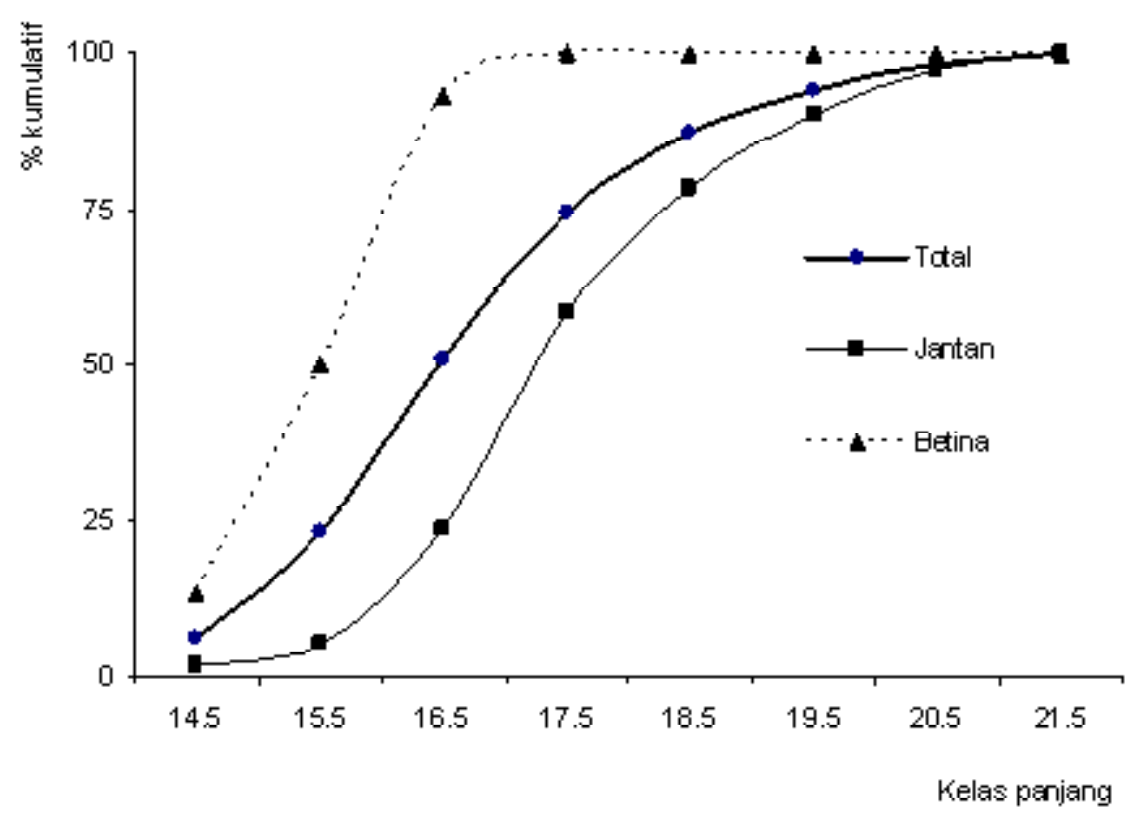

Gambar 5. Panjang rata-rata (50\% kumulatif) ikan coklatan (S. taeniopterus) jantan dan betina (bulan Agustus 2006, di Laut Jawa).

Figure 5. Mean length (cummulative 50\%) of male and female lattice monocle bream (S. taeniopterus), (cantrang's catch sample in August 2006, from the Java Sea).

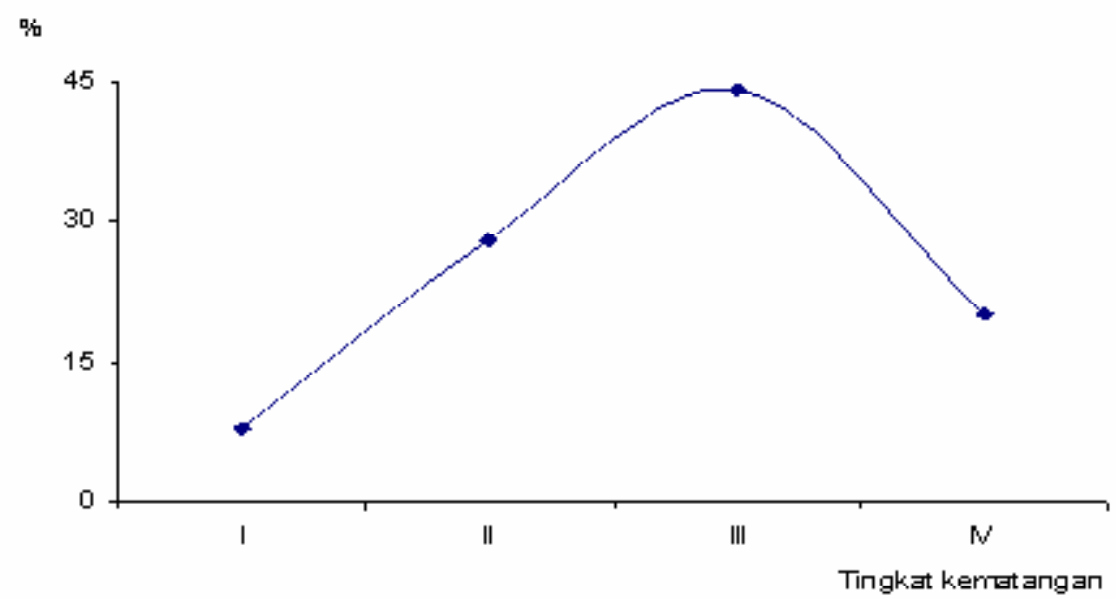

Gambar 6. Tingkat kematangan ovarium ikan coklatan (S. taeniopterus) betina (bulan Agustus 2006, di Laut Jawa).

Figure 6. Maturity stage of female lattice monocle bream (S. taeniopterus) (cantrang's catch sample in August 2006, from the Java Sea).

untuk mengerombol di luar daerah penangkapan. Dengan kata lain, kelompok ikan coklatan berukuran kecil diduga berada pada habitat yang berbeda dengan kelompok ikan yang berkuran lebih besar.

Pada kegiatan percobaan seleksi mata jaring (mesh selection experiment) yang dilakukan oleh
Marine Research Department, Southeast Asian Fisheries Development Center di perairan Laut Cina Selatan, dikatakan bahwa panjang ikan coklatan saat pertama kali tertangkap, Lc=14,7 cm (Sinoda et al., 1979). Berdasarkan pada hasil penelitian tersebut, tampak bahwa rata-rata ukuran ikan coklatan yang tertangkap relatif lebih kecil. 


\section{Tingkat Kematangan dan Panjang Saat Pertama Matang Ovarium}

Dari 75 ekor ikan betina tampak bahwa tingkat kematangan ovarium berada antara tingkat I sampai dengan IV. Dari contoh yang diambil pada bulan Agustus 2006 tersebut tampak bahwa ikan coklatan betina didominasi oleh kelompok ikan dengan tingkat kematangan ovarium III atau matang (Gambar 6). Dengan demikian, diduga bahwa stok ikan coklatan tersebut dalam beberapa waktu mendatang akan segera memasuki periode spawning time.

Dari analisis kematangan ovarium, dapat dihitung ukuran ikan untuk pertama kali matang ovarium, $\mathrm{Lm}=15,0 \mathrm{~cm}$ (Lampiran 1). Dari dimensi ukuranukuran tersebut dapat disimpulkan bahwa sebagian besar ikan coklatan yang tertangkap sudah melewati ukuran pertama kali matang gonad, Lc $>$ Lm. Dari fenomena tersebut diduga bahwa kelompok ikan coklatan berkuran kecil mempunyai kebiasaan untuk berada pada daerah penyebaran yang berbeda dengan ikan berkuran besar. Jika kondisi tersebut dapat terus dipertahankan, maka stok ikan coklatan pada tingkat upaya yang relatif sama mempunyai peluang yang lebih besar untuk dimanfaatkan secara berkelanjutan.

\section{KESIMPULAN}

1. Kepadatan stok ikan coklatan (S. taeniopterus) pada bulan Desember 2005 lebih rendah dibanding bulan Mei 2006, diduga disebabkan ada fluktuasi musiman.

2. Sebaran panjang ikan coklatan secara keseluruhan, terdapat satu kohort yang kuat (strong cohort) pada modus ukuran panjang sekitar $16,5 \mathrm{~cm}$. Setelah dipisahkan antara kelompok ikan jantan dan betina, terdapat perbedaan ukuran ratarata panjang pertama kali tertangkap (Lc) antara ikan betina ( $\mathrm{LC}=15,5 \mathrm{~cm})$ dan ikan jantan ( $\mathrm{LC}=17,5$ $\mathrm{cm})$.

3. Ukuran ikan pertama kali matang adalah $\mathrm{Lm}=15,0$ $\mathrm{cm}$. Berdasarkan pada perhitungan tersebut, sebagian besar ikan coklatan yang tertangkap sudah melewati ukuran pertama kali matang gonad (LC>Lm).

\section{PERSANTUNAN}

Kegiatan dari hasil riset pengkajian stok life history dan dinamika populasi sumber daya ikan demersal dan udang penaeid di perairan Laut Cina Selatan, Laut Jawa, dan Selat Makassar, T.A. 2005 dan 2006, di Balai Riset Perikanan Laut-Muara Baru, Jakarta.

\section{DAFTAR PUSTAKA}

Anonymous. 2006. Cruise R/V Bawal Putih I. Laporan Teknis Intern. Balai Riset Perikanan Laut.

Anonymous. 2006a. Cruise R/V Sardinella. Laporan Teknis Intern. Balai Riset Perikanan Laut.

Anonymous. 2006b. Laporan teknis intern (riset pengkajian stok dan life history ikan demersal dan udang penaeid di Laut Cina Selatan, Laut Jawa, dan Selat Makassar). Balai Riset Perikanan Laut.

Badrudin. 1987. The recovery of demersal fish stock and the stock parameters of the splendid pony fish, Leiognathus splendens, in the north coast of Central Java, Indonesia. MS. thesis. School of Animal Biology. University College of North Wales. Bangor. UK. 57 p.

Beck, U. \& A. Sudradjat. 1979. Variation in size and compositionof demersal trawl catches from the north coast of Java with estimated growth parameters fro three important food fish species. Special Report. Contribution of Demersal Fisheries Pro. No.7-1979. LPPL-GTZ. 80 p.

Delsman, H. C. 1932. Fish eggs and larvae from the Java Sea. 19. The genus Setipina. 20 The genus Coilia. Treubia. 14 (1): 109-116.

Fischer, W. \& P. J. P.Whitehead (eds). (1974). FAO species identification sheets for fishery purposes. Eastern Indian Ocean and Western Central Pacific. FAO-UN. Rome.

Gloerfelt-Tarp, T. \& P. Kailola. 1985. Trawled fish of the southern Indonesia and northern Australia. ADAB-GTZ-DGF Indonesia.

Holden, M. J. \& D. F. S. Raitt. 1974. Manual of Fisheries Science. FAO. Rome. Part 2. Methods of Resources Investigation and their Application. 135.

Losse, G. F. \& A. Dwiponggo. 1977. Report on the Java Sea southeast monsoon trawl survey June until December 1976. Special Report. Contribution of Demersal Fisheries Pro. No.3-1977. LPPL-GTZ. $119 \mathrm{p}$. 
Martosubroto, P. 1982. Fisheries dynamic of demersal resources of the Java Sea. Ph.D. Thesis. Dalhousie University. Canada. (unpublished). 238 p.

Munro, I. S. R. 1955. The marine and freshwater fish of Ceylon. Dept. of External Affairs. Canberra. 351 $\mathrm{p}+56 \mathrm{pl}$.

Munro, I. S. R. 1967. The fishes of New Guinea. Departmen of Agriculture, Stock, and Fisheries. Port Moreby. New Guinea. 651 p+78 pl.

Nakabo, T (Ed). 2002. Fishes of Japan with pictorial keys to the species. English edition. Tokai University Press. Book I. 866 p. Book II. 867-1748.

Rawlinson, N. J. F., D. A. Milton, S. J. M. Blaber, A. Sesewa, \& S. P. Sharma. 1995. A survey of the subsistence and artisanal fisheries in rural areas of Viti Levu. Fiji. ACIAR Monograph. No.35. 138 p.
Russell, B. C. 1998. Nemipteridae. In Carpenter, K. E. and V. H.Niem (Eds). FAO Species identification guide for fishery purposes. The living marine resources of the Western Central Pacific. Bony fishes. Part 3. FAO-UN. Rome. Vol.5: 280-323.

Sinoda, M., S. M. Tan, Y. Watanabe, \& Y. Meemeskul. 1979. A method for estimating the best cod end mesh size in the South China Sea area. Bulletin Chosi Lab.Chiba University. 11: 6580.

Saeger, J., Martosubroto P., \& D. Paully. 1976. First report of the Indonesian-German demersal fisheries project (result of atrawl survei in the Sunda Shelf Area). Special Report. LPPL and GTZ. 1-46.

Udupa, K. S. 1986. Statistical method of estimating the size of first maturity in fish. Fishbyte. ICLARM. Manila. Vol.4 No.2 August 1986: 8-1. 
Kelimpahan Stok, Sebaran Panjang, .... di Perairan Laut Jawa (Ernawati, T. \& Badrudin)

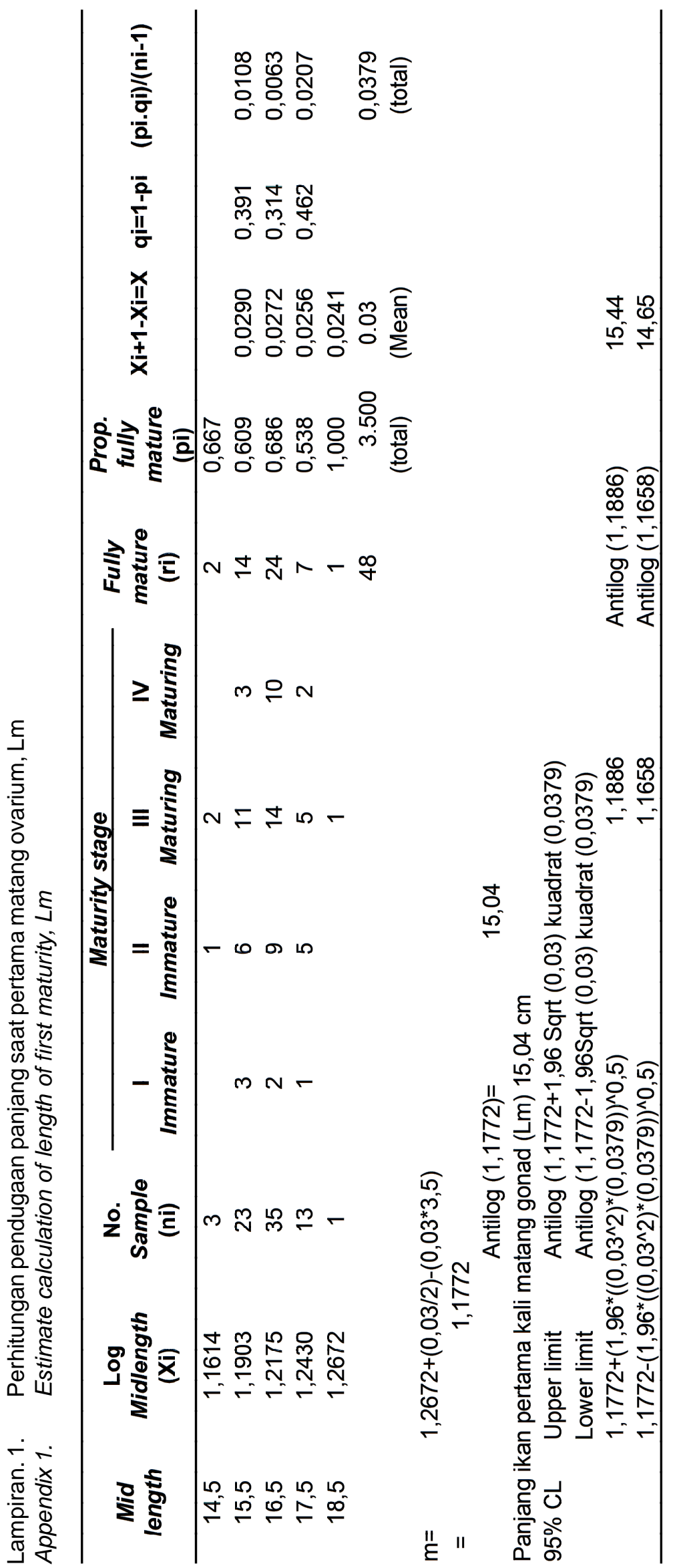

